\title{
The Taming of Evolution
}





\section{The Taming \\ of Evolution}

The Persistence of

Nonevolutionary Views

in the Study of Humans

by Davydd J. Greenwood

Cornell University Press

Ithaca and London 
Passages from On Human Nature and Sociobiology, by E. O. Wilson, and from Genes, Mind, and Culture, by Charles Lumsden and E. O. Wilson, are reprinted by permission of Harvard University Press.

Passages from the following books are reprinted by permission of Random House, Inc., and Alfred A. Knopf, Inc.: The Spanish Temper, by V. S. Pritchett, copyright (C) 1954 by V. S. Pritchett; Cows, Pigs, Wars, and Witches, by Marvin Harris, copyright (C) 1974 by Marvin Harris; Cannibals and Kings, by Marvin Harris, copyright (C) 1977 by Marvin Harris; Cultural Materialism, by Marvin Harris, copyright (C) 1979 by Marvin Harris.

Passages from America Now, by Marvin Harris, copyright (C) 1981 by Marvin Harris, are reprinted by permission of Simon \& Schuster, Inc.

Passages from Six Books of the Commonwealth, by Jean Bodin, translated by M. J. Tooley, are reprinted by permission of Basil Blackwell, Ltd.

Passages and photographs from Physique and Character, by Ernst Kretschmer, translated by W. J. H. Sprott, are reprinted by permission of Springer-Verlag.

Passages and photographs from The Varieties of Human Physique, by W. H. Sheldon, are reprinted by permission of the Trustees of the Estate of W. H. Sheldon.

\section{Copyright (C) 1984 by Cornell University}

All rights reserved. Except for brief quotations in a review, this book, or parts thereof, must not be reproduced in any form without permission in writing from the publisher. For information, address Cornell University Press, Sage House, 512 East State Street, Ithaca, New York 14850, or visit our website at cornellpress.cornell.edu.

First published 1984 by Cornell University Press

Library of Congress Cataloging-in-Publication Data

Greenwood, Davydd J.

The taming of evolution.

Bibliography: $\mathrm{p}$.

Includes index.

1. Human evolution. 2. Nature and nurture. 3. Sociobiology. 4. Physical anthropology-Philosophy. I. Title.

GN281.G73 $1984 \quad 573 \quad 84-45147$

ISBN-13: 978-0-8014-1743-6 (cloth)

ISBN-13: 978-1-5017-1988-2 (pbk.)

The text of this book is licensed under a Creative Commons Attribution-NonCommercial-NoDerivatives 4.0 International License: https://creativecommons.org/licenses/by-nc-nd/4.0/ 
For

Julio Caro Baroja

maestro y amigo 
